ISSN 0814-0626

\title{
Australian Journal of
}

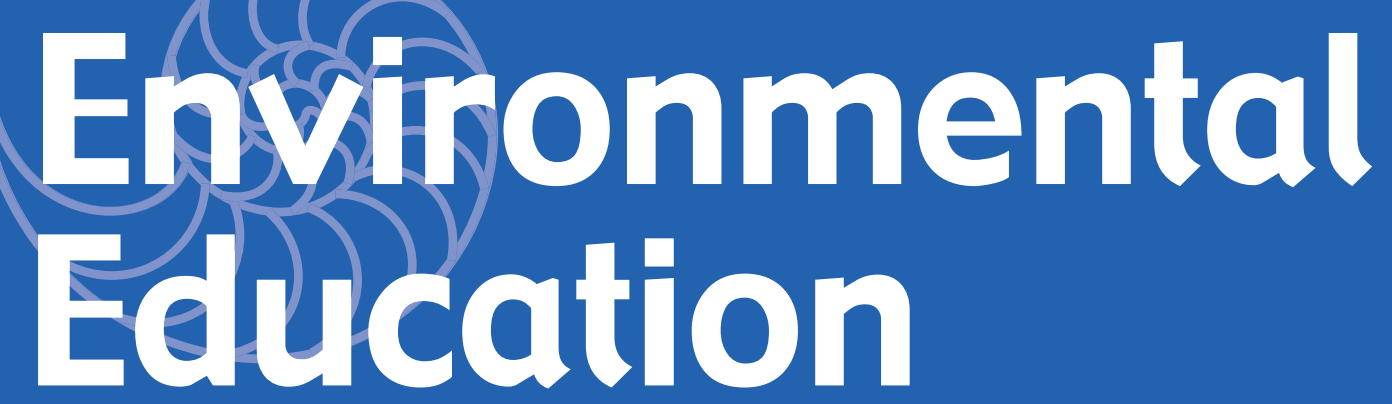

\author{
Editor: Amy Cutter-Mackenzie
}

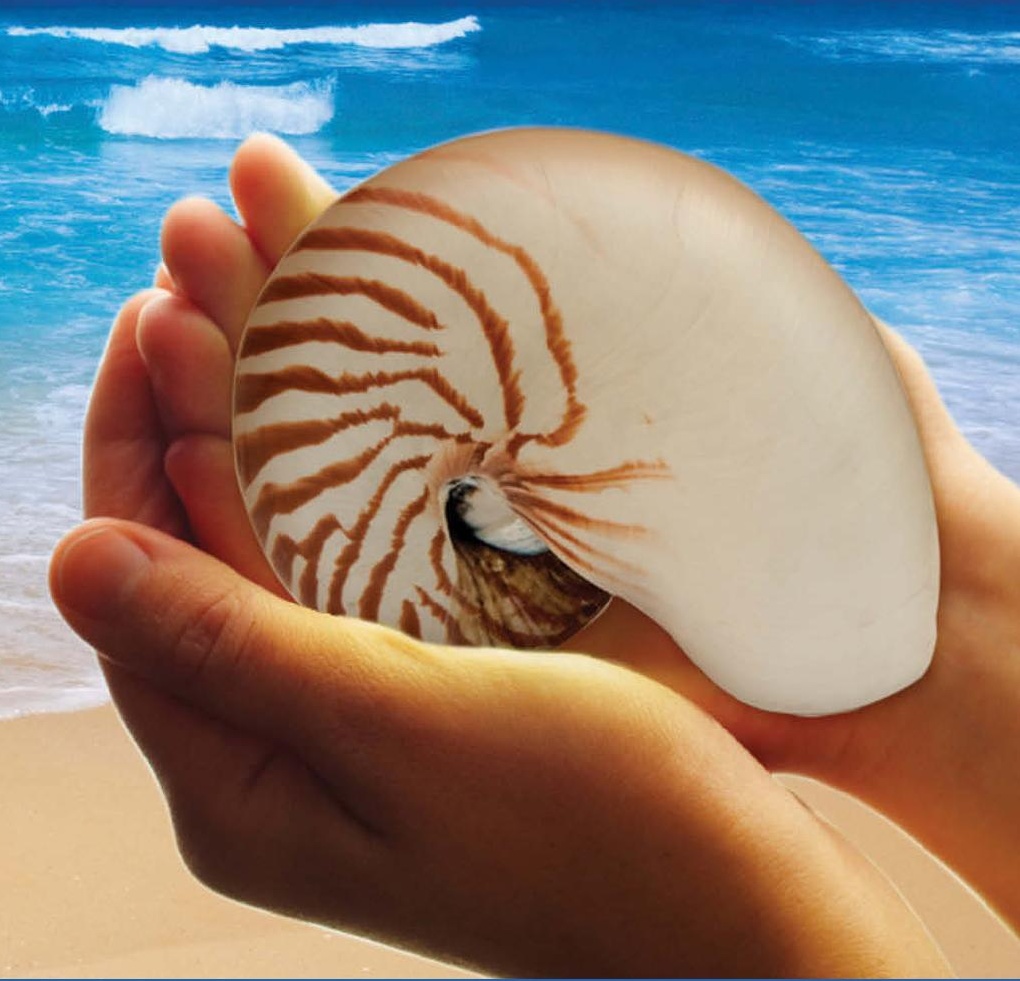


The Australian Journal of Environmental Education is an international refereed journal that publishes papers and reports on all aspects of environmental education. It is the journal of the Australian Association for Environmental Education. It is produced in order to present information and argument that will stimulate debate about educational strategies that enhance the kinds of awareness, understanding and actions that promote environmental and social justice. The journal is addressed to educators working in any educational setting where these matters are centrally or peripherally considered.

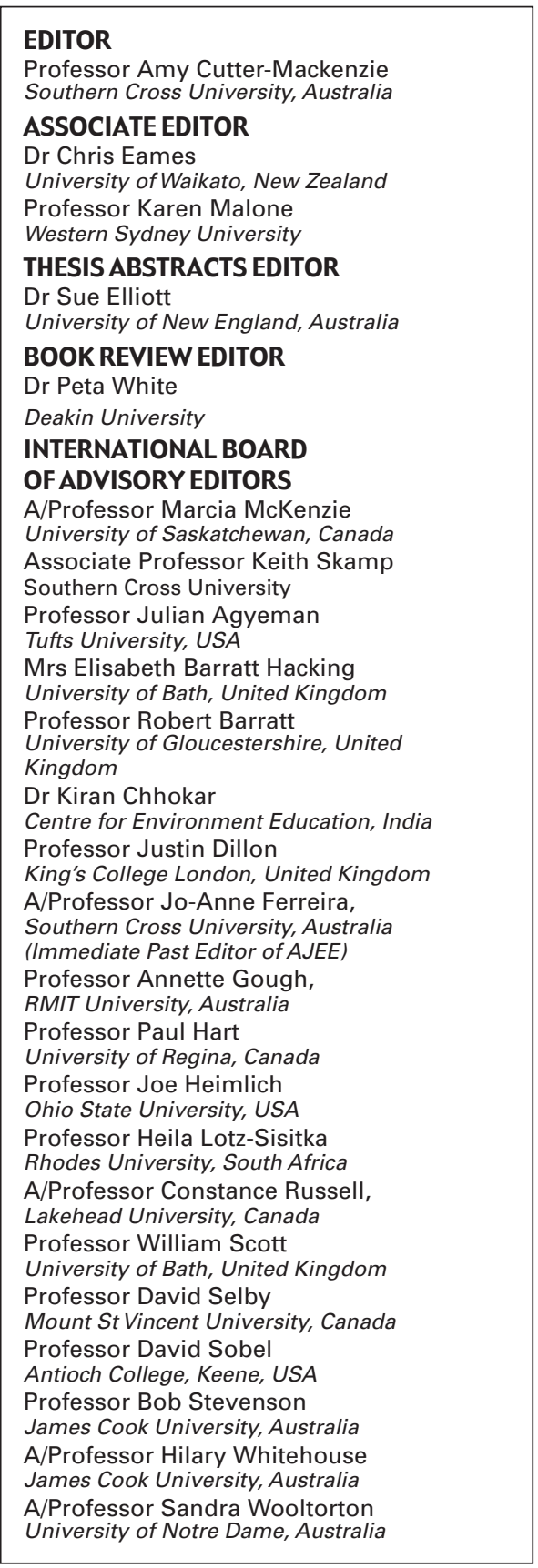

\section{SUBSCRIPTION RATES 2018}

This journal is published triannually.

The institutional rates (excluding VAT) are:

$\begin{array}{lcc} & \text { Print and online } & \text { Electronic Only } \\ \text { Australia } & 353 \mathrm{AUD} & 331 \mathrm{AUD} \\ \text { N America } & 269 \mathrm{USD} & 255 \mathrm{USD} \\ \text { UK and ROW } & 170 \mathrm{GBP} & 159 \mathrm{GBP}\end{array}$

EU subscribers (outside the UK) who are not registered for VAT should add VAT at their country's rate. VAT registered subscribers should provide their VAT registration number. Prices include delivery by air when appropriate. Japanese prices for institutions are available from Kinokuniya Company Ltd, P.O. Box 55, Chitose, Tokyo 156, Japan.

\section{Orders and subscription enquiries should be} addressed to:

Cambridge University Press, Journals Fulfillment Department, UPH, Shaftesbury Road, Cambridge CB2 8BS, UK

Email: journals@cambridge.org

Orders from N America should be addressed to:

Cambridge University Press, 1 Liberty Plaza, New York, NY 10006, USA

Email: subscriptions_newyork@cambridge.org

The Australian Journal of Environmental Education and all other Cambridge Journals can be found at journals. cambridge.org/

Published by Cambridge University Press. All rights reserved. No part of this publication may be reproduced in any form or by any means, electronic, photocopying or otherwise, without permission in writing from Cambridge University Press.

Permission to copy (for users in the USA) is available from Copyright Clearance Center, www.copyright.com, email: info@copyright.com.

\section{The Nautilus}

The Association logo is the nautilus. It is used by the Association to symbolise the "wisdom of the

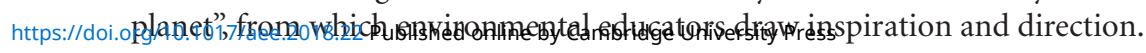




\title{
Australian Journal of Environmental Education
}

\author{
Volume 34(1) 2018
}

\section{Contents}

\section{FEATURE ARTICLES}

Fieldwork, Sustainability, and Environmental Education: The

Centrality of Geographical Inquiry

Niranjan Casinader \& Gillian Kidman ................................ 1

Education Agendas and Resistance With the Teaching and Learning of

Freshwater and Extreme Freshwater Events

Alison Sammel, Dena McMartin \& Katherine Arbuthnott ...

Underwater Photo-Elicitation: A New Experiential Marine Education

Technique

Steve Andrews, Laura Stocker \& Walter Oechel

NEP (Children@School): An Instrument for Measuring Environmental

Attitudes in Middle Childhood

Parisa Izadpanahi \& Richard Tucker

61

\section{BOOK REVIEWS}

Aboriginal and Torres Strait Islander Education: An Introduction for the

Teaching Profession

Jeddah Teasdale

Grassroots Innovation Movements

Meredian Alam

Nature and Human Nature - Two Perspectives

Annette Gough

Place, Being, Resonance: A Critical Ecohermeneutic Approach to

Education

David Wright

Routledge Handbook of Higher Education for Sustainable Development

Jonathon Howard

\section{THESIS SYNOPSIS}

Pre-Service Early Childhood Teachers' Preparedness to Teach Education for Sustainability

Anita Croft. 